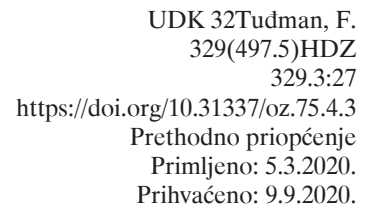

\title{
Franjo Tuđman, demokršćanstvo i Hrvatska demokratska zajednica
}

\author{
Jakov Žižić*
}

\begin{abstract}
Sažetak
Ovaj se rad bavi odnosom Franje Tuđmana prema demokršćanskoj orijentaciji Hrvatske demokratske zajednice (HDZ) i njegovim razumijevanjem demokršćanstva. Prikazana su Tudmanova stajališta o političkom identitetu HDZ-a te je objašnjena transformacija HDZ-a u stranku demokršćanske orijentacije na stranačkom saboru 1993. godine. Analiza je pokazala da programsko opredjeljenje HDZ-a za demokršćanstvo nije za Tuđmana značilo da ta stranka treba napustiti svoj nadideološki i svehrvatski politički identitet i pretvoriti se u izričito demokršćansku stranku. Istraživanje je također utvrdilo kako je Tuđmanovo razumijevanje demokršćanstva bilo puno bliže konfesionalnoj nego suvremenoj fazi demokršćanstva, premda je po nekim obilježjima Tuđman bio blizak i suvremenomu obliku demokršćanske ideologije.
\end{abstract}

Ključne riječi: Franjo Tuđman; Hrvatska demokratska zajednica; demokršćanstvo; demokršćanske stranke; hrvatska politika

\section{Uvod}

U hrvatskom javnom diskursu postoje različita tumačenja odnosa Franje Tuđmana ${ }^{1}$ prema demokršćanstvu i njegove vizije Hrvatske demokratske zajednice (HDZ) $)^{2}$ kao demokršćanske stranke. Spomenute su razlike sastavni dio rasprava i prijepora o političkom identitetu današnjega HDZ-a, koji sebe definira kao stranku koja promiče demokršćanske vrijednosti te slijedi političko nasljeđe Franje Tuđmana (HDZ, 2018, 3). Različita tumačenja Tuđmanova odnosa prema demokršćanstvu i demokršćanskoj orijentaciji HDZ-a prvenstveno se izražavaju u izjavama bivših i sadašnjih čelnika HDZ-a. Nekadašnji visoki dužnosnik

* Dr. sc. Jakov Žižić, asistent, Hrvatsko katoličko sveučilište. Adresa: Ilica 242, 10000 Zagreb, Hrvatska. ORCID iD: https://orcid.org/0000-0002-1451-0381. E-adresa: jakovzizic@unicath.hr

1 Franjo Tuđman (1922.-1999.), hrvatski povjesničar i političar; predsjednik HDZ-a od 1989. do 1999. i Republike Hrvatske od 1990. do 1999. godine.

2 Hrvatska demokratska zajednica (HDZ), politička stranka desnoga centra osnovana 1989. i formalno registrirana 1990. godine. 
HDZ-a Stjepan Mesić3 ${ }^{3}$ ističe kako Tuđman nikad nije rekao da je HDZ demokršćanska stranka (Anon., 2020a). Prema Mesiću, Tuđman nikad nije dopustio da se predznak demokršćanstva stavi u HDZ, smatrajući kako ta stranka »mora biti na bazi Ante Starčevića, Stjepana Radića i hrvatske ljevice« (Anon., 2016). Jadranka Kosor, koja je u drugoj polovici 90-ih bila podpredsjednica HDZ-a, navodi da Tuđman nije zamislio HDZ kao demokršćansku stranku, niti je u programu nikada napisao da je HDZ demokršćanska stranka. Kosor tvrdi kako je Tuđman uvijek govorio da je HDZ narodnjačka stranka koja okuplja široki spektar, držeći se postulata da HDZ treba biti puno šira stranka od demokršćanske desnice. Kosor ističe i kako »ne postoji neki relevantan stranački dokument niti odluka Sabora HDZ-a o transformaciji HDZ-a iz narodnjačke u demokršćansku stranku « (Karlović-Sabolić, 2018).

S druge strane, predsjednik HDZ-a Andrej Plenković4 ističe kako je »Tuđman HDZ vrijednosno pozicionirao na desnom centru «, pri čemu desni centar »znači i narodnjaštvo i demokršćanstvo i državnotvornost i domoljublje i univerzalne i europske vrijednosti « (Hina, 2018). Plenković smatra kako je Tuđman postavio čvrste temelje HDZ-a koji uključuju »desni centar, narodnjaštvo i okupljanje demokršćanskih načela, odnosno svih vrijednosti na kojima se zasniva politička platforma i program HDZ-a « (Hina, 2017). Prema zastupniku HDZ-a u Europskom parlamentu Tomislavu Sokolu »HDZ se temelji na vrijednostima koje je definirao prvi predsjednik Franjo Tuđman, a to su demokršćanstvo, narodnjaštvo, državotvorstvo, domoljublje, temeljne humanističke vrijednosti, koje su i u našem novom statutu « (Krnetić, 2019).

Cilj je ovoga rada utvrditi stajalište Franje Tuđmana o HDZ-u kao stranci demokršćanske orijentacije te objasniti njegov odnos prema demokršćanstvu. U prvom dijelu rada prikazani su izvori, evolucija i obilježja demokršćanstva. U drugom dijelu rada donosi se pregled povijesnoga razvoja demokršćanstva u Hrvatskoj i uloge demokršćanskih stranaka u hrvatskom političkom životu tijekom 90 -ih godina 20 . stoljeća. U trećem dijelu rada analizira se politički identitet HDZ-a i profiliranje te stranke u smjeru demokršćanstva u razdoblju dok je Franjo Tuđman bio njezin predsjednik. U završnom dijelu rada daje se zaključni osvrt na Tuđmanov odnos prema demokršćanskoj orijentaciji HDZ-a i njegovo razumijevanje demokršćanstva. U radu se koriste primarni (transkripti sjednica državnih i stranačkih tijela) i sekundarni izvori (stranačke publikacije i dokumenti) te postojeća znanstvena literatura.

3 Stjepan Mesić (1934.), hrvatski političar; glavni tajnik HDZ-a 1990., HDZ-ov predsjednik hrvatske Vlade 1990. i Zastupničkog doma Sabora od 1992. do 1994. godine.

4 Andrej Plenković (1970.), hrvatski diplomat i političar, predsjednik HDZ-a i hrvatske Vlade od 2016. godine. 


\section{Izvori, evolucija i obilježja demokršćanstva}

\subsection{Konfesionalne stranke}

Suvremene demokršćanske stranke razvile su se iz katoličkih konfesionalnih stranaka ${ }^{5}$ stvorenih tijekom druge polovice 19 . i prve polovice 20. stoljeća (Kalyvas i Kersbergen, 2010, 185). Konfesionalne stranke bile su proizvod rascjepa između države i Crkve, koji je potaknulo formiranje liberalnih nacionalnih država u Europi u 19. stoljeću. Nova liberalna sekularna država borila se je protiv utjecaja Crkve u društvu, a napose protiv njezine uloge u obrazovanju. Obvezatno državno obrazovanje korišteno je za "kovanje" građana s novim (nereligijskim) vrijednostima, što je osobito u katoličkim zemljama uzrokovalo snažne sukobe, a u protestantskim zemljama - u kojima crkve pripadaju državi, taj se je rascjep usredotočio na moralna načela (Caramani, 2013, 238). Kako ističe Paolo Pombeni $(2006,123)$, Katoličkoj crkvi bilo je teže nego reformiranim kršćanskim crkvama djelovati u svijetu nastalom poslije liberalne revolucije jer je Katolička crkva u biti tvrdila da je upravo ona, jezikom njezinih jurista, societas perfecta, odnosno izvorni pravni entitet ravnopravan s drugim izvornim pravnim entitetima (dotad svedenim samo na države).

Konfesionalne stranke bile su prvenstveno stranke obrane katoličkih i crkvenih interesa. Bile su rezervirane prema parlamentarnoj demokraciji i stoga ih se ne može smatrati kršćansko-demokratskim, odnosno demokršćanskim strankama. No termin kršćanska demokracija potkraj 19. i na prijelazu u 20. stoljeću imao je i drugačije značenje od današnjega te je označavao pokret unutar Katoličke crkve koji se je prvenstveno trebao brinuti za siromahe i radnike. Tako shvaćena kršćanska demokracija nije se odnosila na političke ideje i zadaće te je ostala izvan političkih stranaka i vlada (Baloban, 1995, 34). Konfesionalne stranke bile su antikapitalistički orijentirane, što je bilo povezano s naglašenom antipatijom Katoličke crkve prema kapitalizmu, koji je smatrala ekonomskim oblikom liberalnoga političkoga sustava (Pombeni, 2006, 125). U enciklici Rerum novarum iz 1891. papa Lav XIII. (1878.-1913.) oštro je osudio liberalni kapitalizam, koji je smatrao odgovornim za loše životne uvjete radnika. Papa je negirao klasnu borbu i zagovarao klasni mir i suradnju te tražio primjerenu plaću za radnike te da se s njima ne postupa kao s robovima i sredstvima (Cvrlje, 1994, 58). Enciklika Rerum novarum bila je temelj katoličkoga socijalnoga nauka i idejna osnova konfesionalnih (katoličkih) i demokršćanskih stranaka. Oblikovanje katoličkoga socijalnoga nauka nastavljeno je enciklikom Quadragesimo anno iz 1931., u kojoj je papa Pio XI. (1922.-1939.) ponovio i produbio misli Lava XIII. te pružio obrise vizije političkoga uređenja prema kršćanskim načelima, posebice na temelju društvene solidarnosti i supsidijarnosti u odlučivanju (Raos, 2014).

Konfesionalne su stranke najčešće bile povezane s katoličkim društvenim pokretima, premda odnos između to dvoje ni u kojem slučaju nije podupirao nasta-

5 S iznimkom kalvinističkih stranaka u Nizozemskoj, sve druge konfesionalne stranke bile su katoličke. 
nak političkih stranaka (Hanley, 1994, 3). Premda su bili predvođeni od strane Katoličke crkve, koja je nastojala zaštiti svoja prava u području obrazovanja, katolički društveni pokreti stekli su svoju autonomiju od Crkve kroz transformaciju u političke stranke (Kalyvas i Kersbergen, 2010, 185). Djelujući unutar liberalne ustavne države, konfesionalne stranke s vremenom su stekle značajan politički utjecaj, osobito u Belgiji i Njemačkoj. Premda su prvotno bile ideološki suprotstavljene parlamentarnoj demokraciji, konfesionalne stranke ubrzo su shvatile da se njihov interes nalazi u konsolidaciji i daljnjem širenju parlamentarne demokracije, koja im je pružala političku i društvenu moć (Kalyvas i Kersbergen, 2010, 185). Može se reći kako su konfesionalne stranke negdje oko 1914. općenito postale naklonjene parlamentarnoj demokraciji (premda je bilo nekih bitnih izuzetaka, napose izvan zapadne Europe) te politikama socijalne države, ostajući istodobno na braniku prava i institucija Katoličke crkve, napose škola. Te su se stranke kvalitativno razlikovale od liberalnih i socijalističkih opcija (koje su bile sekularistički orijentirane), ali i od konzervativnih skupina koje su se također pozivale na religiju, ali samo kao dodatak drugim načelima kao što su poredak, tradicija, hijerarhija ili interes pojedinca (Hanley, 1994, 3). Politička emancipacija katoličkih aktivista od Crkve ojačala je zasebni katolički politički identitet, koji je ne samo reinterpretirao katoličanstvo u mnogo manje doktrinarnom smislu, nego je i izazivao religijski primat Crkve u političkim pitanjima. Kao rezultat toga političko katoličanstvo postalo je odvojeno od Crkve i religije, čime je na paradoksalan način politizacija religije pridonijela sekularizaciji politike (Kalyvas i Kersbergen, 2010, 186).

\subsection{Demokršćanske stranke}

Istodobno s razvojem političkoga katoličanstva, koji je okvir svojega djelovanja pronalazio u parlamentarnoj demokraciji, evoluirao je i odnos Katoličke crkve prema demokraciji. Crkva nije doktrinarno odbacivala demokraciju, ali joj nije davala nikakvu prednost u odnosu na druge političke poretke, držeći se teze pape Lava XIII. o jednakom odnosu Crkve prema svim političkim režimima ako oni poštuju prava osobe, obitelji i Crkve (Baloban, 1995, 32). Tek je Papa Pio XII. (1939.-1958.) u svojem radijskom govoru emitiranom na Božić 1944. službeno legitimirao demokraciju kao prirodnu političku formu najbližu Crkvenom mišljenju. Crkvena potpora demokraciji proizišla je, s jedne strane, zato što je bila alternativa komunizmu time što je jamčila slobodu društvenih organizama (a time sljedstveno i Crkve), a s druge strane, jer su njom istodobno upravljala načela nametnute volje većine i zaštite manjine, pa je time išla u prilog katolicizmu ma u kojoj se od dvije pozicije našao (Pombeni, 2006, 131).

Potpuno prihvaćanje demokracije od strane konfesionalnih stranaka i crkvene hijerarhije dovelo je do pojave suvremene kršćanske demokracije, koja je svoj zamah dobila nakon Drugoga svjetskoga rata. Kršćanska demokracija snažno je utjecala na politički i društveni razvoj poslijeratne zapadne Europe. U poslijeratnoj demokratskoj Europi kršćansko-demokratske stranke imale su ključnu ulogu u: prvo, učvršćivanju novih stranačkih sustava; drugo, legitimiranju tržišne 
ekonomije kroz socijalnu sigurnost i uvođenje korporativističkih oblika konsenzusnoga stvaranja socijalnih i ekonomskih politika; treće, zaustavljanju nacionalnih tenzija i suparništava izgradnjom nadnacionalne Europske unije (Kalyvas i Kersbergen, 2010, 185). U poslijeratne ustave Francuske, Italije i Njemačke uvedena su načela kršćanske demokracije: 1 . središnje mjesto "osobe" kao pravnoga subjekta i društvenoga entiteta koji posjeduje konkretne atribute i prava; 2. pretežito "socijalno" shvaćanje ekonomije s umjerenom količinom kontrole nad kapitalističkim sustavom; 3. obrana ne-državnih socijalnih entiteta (od obitelji do crkava); 4. valorizacija oblika organizacije, i političkih (stranaka) i korporativnih (sindikata) (Pombeni, 2006, 131).

Katoličanstvo i Katolička crkva bili su osnova koja je omogućila razvoj kršćansko-demokratskih stranaka poslije Drugoga svjetskoga rata (Pelinka, 2004, 178). Demokršćanske stranke razvile su se u većinski katoličkim državama poput Italije, Francuske, Belgije i Austrije, kao i među katoličkom manjinom u većinski protestantskim državama poput Nizozemske i Švicarske, gdje su bile sredstvo borbe protiv protestantske dominacije. Demokršćanske stranke nisu se razvile ili imale važnu ulogu u pretežito protestantskim državama ili kao specifično protestantski fenomen u državama s mješovitom (protestantskom i katoličkom) vjerskom strukturom (Pelinka, 2004, 178). Samo su u Njemačkoj CDU (Kršćansko-demokratska unija) i CSU (Kršćansko-socijalna unija) povezale katoličku osnovu s protestantizmom i pozicionirale se kao međukonfesionalne stranke koje uživaju bitnu potporu i među katolicima i protestantima.

Politički programi poslijeratnih demokršćanskih stranaka bili su oblikovani na zasadama katoličkoga socijalnoga nauka naglašavajući središnju važnost ljudske osobe te načela solidarnosti i supsidijarnosti (Milardović, 1994, 37). Unatoč oslanjanju na katoličko socijalno učenje, suvremene demokršćanske stranke ne može se izjednačavati s Katoličkom crkvom i njezinim učenjem. Demokršćanska politička ideologija puno je šira od učenja Katoličke crkve jer demokršćanski politički i društveni pokreti nadilaze društvenopolitičku misao i praksu Katoličke crkve (Kalyvas i Kersbergen, 2010, 187). Demokršćanske stranke svjesno se deklariraju kao akonfesionalne, koristeći izraz kršćanski kako bi označile inspiraciju koja ih vodi, a to je kršćanska vizija političkoga i socijalnoga morala (Grbac, 2007, 459). Izraz kršćanski u imenu suvremenih demokršćanskih stranaka ne predstavlja njihovu religijsku pripadnost ni povezanost s Crkvom, nego religijsku inspiraciju koju se doživljava na veoma sekulariziran način.

Zatomljivanje religijskoga identiteta i težnja za širenjem biračke osnove na cjelokupno društvo približili su demokršćanske stranke catch-all (narodnom) tipu stranaka, koje ne predstavljaju samo jednu društvenu skupinu, nego se obraćaju biračima iz svih slojeva društva. Demokršćanske su stranke bile jako pogodne za evoluciju u catch-all tip stranke jer su se zbog izvorno religijskoga karaktera oblikovale kao društveno heterogene stranke koje okupljaju različite slojeve društva, odnosno klase. Zbog heterogene društvene osnove demokršćanske su stranke njegovale politiku akomodacije različitih klasnih interesa, što im je omogućilo da se uspješno usmjere na artikuliranje interesa birača iz svih slojeva 
i sektora društva. Njemački CDU čak je uziman kao prototip catch-all stranke koja je 60-ih godina 20. stoljeća postala dominantan tip političke stranke u zapadnoj Europi (Hornig, 2013, 82).

\section{Demokršćanstvo u Hrvatskoj do 1990. godine}

U Hrvatskoj se je početkom 20. stoljeća počeo razvijati katolički pokret koji je okupljao katolike u borbi za vjerska načela i interese. Hrvatski katolički pokret (HKP) razvijao se je pod utjecajem iz Slovenije, a najvažniju ulogu u njegovu konstituiranju, širenju i djelovanju imao je krčki biskup Antun Mahnič, inače podrijetlom Slovenac (Boban, 1995, 200). Unatoč postojanju katoličkoga pokreta i snažnomu društvenomu utjecaju Katoličke crkve, u Hrvatskoj se na početku 20. stoljeća nije razvila utjecajna konfesionalna (katolička) stranka, kao što je to bio slučaj u Sloveniji ili Austriji. ${ }^{6}$ Biskup je Mahnič inače podržavao političko organiziranje katolika preko političke stranke, no nakon što je splasnuo početni entuzijazam o lakoći osnivanja jedne takve stranke u Hrvatskoj, zaključio je da se HKP do daljnjega mora zadovoljiti samo radom na socijalnom polju (Matijević, 1997, 449). Treba kazati kako u ondašnjoj Hrvatskoj, unatoč određenim namjerama, nije došlo do provođenja crkveno-političkih reformi liberalnoga značaja (Strecha, 2004, 102) pa samim time nije bilo ni rascjepa između države i Crkve koji bi stvorio strukturne preduvjete za razvoj konfesionalne stranke. Također, većina ondašnjega katoličkoga svećenstva smatrala je da je borba s liberalizmom u Hrvatskoj promašena i suvišna, ako ne i štetna, jer nepotrebno dijeli narodnu snagu i dijeli njezine dijelove (Jukić, 2001, 6).

Premda se iz HKP-a nije razvila snažna katolička stranka, u Hrvatskoj je na prijelazu iz 19. u 20. stoljeća došlo do pojave političkih stranaka i skupina koje su se nadahnjivale načelima katoličkoga socijalnoga nauka. Krajem 90-ih godina 19. stoljeća pod vodstvom kapelana Stjepana Zagorca pokrenuta je Hrvatska radnička zajednica, a 1904. zaživjela je kršćansko-socijalna skupina okupljena oko dnevnika Hrvatstvo, no ni jedna od tih opcija nije se prometnula u jaču stranku (Matković, 2006, 68). Krajem 1904. osnovana je Hrvatska pučka seljačka stranka (HPSS), čiji je vođa i ideolog Stjepan Radić pokazivao simpatije prema katoličkomu socijalnomu nauku i u svojim se saborskim govorima često pozivao na encikliku Rerum novarum pape Leona XIII. Politolog Tihomir Cipek (2004, 341) navodi kako je socijalni program HPSS-a bio u znatnoj mjeri oblikovan kršćansko-demokratskim idejama.

Nestankom Austrougarske Monarhije i stvaranjem Kraljevine Srba, Hrvata i Slovenaca 1918. započela je nova faza u razvoju demokršćanstva u Hrvatskoj. U novostvorenoj jugoslavenskoj državi 1919. osnovana je Hrvatska pučka stranka

6 U Austriji je postojala Kršćansko-socijalna unija koja je osnovana 1893. i predstavljala je prvu pravu masovnu stranku konzervativne orijentacije, a u Sloveniji je od 1905. djelovala Slovenska pučka stranka, koja je bila najutjecajnija politička stranka u slovenskom društvu sve do Drugoga svjetskoga rata (Cipek, 2006, 26 i 31). 
(HPS) čija su pokretačka snaga bili članovi Seniorata, laičke organizacije koja je imala vodeću ulogu u HKP-u. Članovi Seniorata nisu međutim nikada poistovjećivali tu organizaciju s HPS-om, koji je bio samo jedan aspekt njihova djelovanja u Kraljevini SHS (Matijević, 1997, 442). U pogledu nacionalnoga pitanja HPS se zalagao za državno i narodno jedinstvo Hrvata, Srba i Slovenaca i stvaranje autonomnih jedinica na konfesionalnoj osnovi. Program HPS-a bio je građen na kršćanskom temelju i u svakom, bilo narodnom, prosvjetnom ili socijalno-gospodarskom političkom pitanju moralo se je tražiti rješenje s kršćanskoga stanovišta (Boban, 1995, 203). HPS nije stekao bitniju biračku podršku i ostao je u sjeni Radićeva HRSS-a (od 1925. HSS), koji se je zbog odlučnoga zalaganja za hrvatski nacionalni identitet i državnu autonomiju prometnuo u glavnu političku snagu Hrvata u jugoslavenskoj kraljevini. Stjepan Radić odbacivao je klerikalizam kao politički pokret koji ide za gospodstvom Crkve i svećenstva u političkom i kulturnom životu, ali je isto tako pobijao liberalni naturalizam po kojem je čovjek po svojoj naravi dobar, kao i racionalni liberalizam, koji svijet bez ostatka tumači isključivo spoznajama ljudskoga uma i razuma (Radja, 1998, 101). U Radićevu političkom programu HRSS-a/HSS-a iz 1921. (Ustav neutralne seljačke republike Hrvatske) ističu se kršćanski temelji morala i odgoja te utvrđuje široka autonomija lokalne samouprave, koja je trebala biti ograničena samo mogućnošću izvršavanja vlastitih poslova, što odgovara načelu supsidijarnosti (Radja, 1998, 103). Upravo je poštovanje i često pozivanje na kršćansku etiku omogućilo HSSu da njegovu ideologiju prihvati hrvatsko seljaštvo prožeto katoličkom kulturom (Cipek, 2016, 16). Prema mišljenju teologa fra Bone Zvonimira Šagija, Radićev HSS zbog antiklerikalizma i pozitivnoga stava prema kršćanskom moralu može se smatrati pretečom demokršćanstva u Hrvatskoj (Cipek, 2004, 346). Demokršćanske političke opcije nisu mogle djelovati u ustaškoj Nezavisnoj Državi Hrvatskoj (1941.-1945.) i komunističkoj Jugoslaviji (1945.-1990.), u kojima nije bio dopušten politički pluralizam.

\section{Demokršćanstvo u Hrvatskoj tijekom 90-ih godina 20. stoljeća}

Slom komunističkoga sustava i ozakonjenje političkoga pluralizma 1990. stvorili su pretpostavke za osnivanje i djelovanje demokršćanskih stranaka u Hrvatskoj. Na prvim slobodnim i kompetitivnim izborima za Sabor SR Hrvatske 1990. sudjelovala je i Hrvatska kršćanska demokratska stranka (HKDS), koja je osvojila tri mandata $(0,85 \%)$ (Mašić, 2010, 69). Na parlamentarnim izborima 1992. HKDS nije uspio osigurati zastupljenost u Saboru, a na istodobnim predsjedničkim izborima njihov kandidat Ivan $\mathrm{Cesar}^{7}$ dobio je svega 1,6\% glasova. U prosincu 1992. došlo je do ujedinjenja HKDS-a i Hrvatske demokratske stranke (HDS) u Hrvatsku kršćansku demokratsku uniju (HKDU), čiji je program bio

7 Ivan Cesar (1936.-1993.), hrvatski književni povjesničar i političar; predsjednik Hrvatske kršćanske demokratske stranke 1990. i ministar u Vladi demokratskoga jedinstva 1991. godine (Brozović, 2000, s. v. Cesar, Ivan). 
oblikovan po uzoru na njemački CDU (Cipek, 2004, 349). Prvi predsjednik HKDU-a bio je Marko Veselica, ${ }^{8}$ istaknuti sudionik reformskoga pokreta Hrvatsko proljeće $^{9}$ i dugogodišnji politički zatvorenik u komunističkoj Jugoslaviji. HKDU je iskazivao velike političke ambicije, ali se nije uspio pozicionirati kao relevantna politička snaga u Hrvatskoj. Na parlamentarnim izborima 1995. HKDU je nastupio u koaliciji s još četiri centrističke i regionalističke stranke te osvojio jedan mandat, a isti je rezultat ponovio na parlamentarnim izborima 2000. u koaliciji s desnim HSP-om. Na parlamentarnim izborima 2003. HKDU nije uspio sačuvati parlamentarni status i nakon toga se je pretvorio u marginalnu stranku. Tijekom 90-ih godina u hrvatskom političkom životu djelovali su i Kršćanski demokrati Međimurja (KDM), ${ }^{10}$ koji su na izborima za Županijski dom Sabora 1997. osvojili jedan mandat u koaliciji s HDZ-om, HKDU-om i HSP-om.

\section{Hrvatska demokratska zajednica i demokršćanstvo za vrijeme Franje Tudmana}

\subsection{Prvi programski dokumenti $H D Z-a$}

Nakon početka demokratske tranzicije vodeću političku ulogu u Hrvatskoj preuzeo je HDZ predvođen osnivačem i prvim predsjednikom Franjom Tuđmanom. Od svojega osnivanja 1989. HDZ je istodobno djelovao kao politička stranka i široki nacionalni pokret za stvaranje samostalne hrvatske države. Franjo Tuđman politički je program HDZ-a zasnovao na tri elementa suvremene hrvatske povijesti - starčevićanskoj ideji hrvatskoga državnoga prava, radićevskom pučkom republikanizmu i tradiciji hrvatske ljevice. U prvom programskom dokumentu HDZ-a iz 1989., koji je pisao sam Tuđman, nisu spomenuti kršćanski temelji ni demokršćanska načela, ali je istaknuta zasluga crkvene inteligencije za održanje i civilizacijski razvitak hrvatskoga naroda. U istom je dokumentu navedeno da HDZ »otvara svoja vrata svim pripadnicima hrvatskog naroda [...] bez obzira na njihove svjetonazore, te idejno-politička i vjerska uvjerenja « (HDZ, 1989, 7). Kršćanska načela i demokršćansko usmjerenje nisu spomenuti ni u prvom djelatnom programu HDZ-a iz 1989. ni u stranačkom programu usvojenom na Prvom općem saboru HDZ-a održanom 1990. u Zagrebu.

Izostanak spominjanja kršćanskih temelja u prvim programskim dokumentima HDZ-a objašnjava se različitim razlozima. Tadašnji saborski zastupnik HDZ-a Božidar Petrač $(1994,113)$ ističe kako je velika većina hrvatskoga naroda prihvatila program HDZ-a, a s obzirom na to da veliku većinu hrvatskoga

8 Marko Veselica (1936.-2017.), hrvatski ekonomist i političar; predsjednik Hrvatske kršćanske demokratske unije od 1992. do 2001. i zastupnik u Hrvatskom saboru od 1995. do 2000. godine (Ravlić, 2009, s. v. Veselica, Marko).

9 Hrvatsko proljeće, naziv za široki društveni pokret u SR Hrvatskoj s kraja 60-ih i početka 70-ih koji je nastojao reformirati političke i ekonomske odnose u jugoslavenskoj federaciji.

10 Kršćanski demokrati Međimurja (KDM), politička stranka osnovana 1992. godine. Predsjednik stranke i njezin zastupnik u Županijskom domu Sabora bio je Vladimir Mesarić. 
naroda čine osobe kršćanskoga, katoličkoga svjetonazora, nije bilo potrebe za posebno isticanje demokršćanske orijentacije stranke. Ivan Markešić $(2007,54)$ pak smatra da se kršćanska tradicija nije spominjala zbog činjenice da je HDZ u početku u svojim redovima imao ne samo mali broj bivših članova Saveza komunista Hrvatske (SKH), počevši od samoga Tuđmana, koji do tada nisu prakticirali vjerski život (dolazak u crkvu, crkvena krštenja, krizme i vjenčanja, crkveni pokopi), nego i veći broj muslimana, posebno onih koji su živjeli u dijaspori.

Treba istaknuti kako se HDZ od samoga osnivanja nastojao oblikovati kao nadideološki svehrvatski pokret koji je sposoban okupiti pristalice iz dviju suprotstavljenih političkih tradicija — tradicije Narodnooslobodilačke borbe (NOB) i tradicije Nezavisne Države Hrvatske (NDH). Na javnoj tribini uoči parlamentarnih izbora 1990. tadašnji politički tajnik HDZ-a Neven Jurica istaknuo je kako »HDZ nije ideološka stranka« te se »ona zalaže za potpunu dezideologizaciju cjelokupnog hrvatskog političkog i društvenog prostora« (Đurić et al., 1990, 83). Jurica je naveo i kako HDZ »ne može biti nazivana niti lijevom niti desnom organizacijom « te je ona "po svom programu oslobođena ideoloških stega i ciljeva « (Đurić et al., 1990, 83). Zamisao o nadideološkom nacionalnom pokretu, koji bi pomirio dotad radikalno suprotstavljene političke snage, trebala je omogućiti HDZ-u da postane stožernom političkom organizacijom hrvatskoga naroda $\mathrm{u}$ Domovini i dijaspori (Nikić Čakar, 2013, 201). Zbog svoje nadideološke prirode HDZ je uspio okupiti raznorodne i suprotstavljene političke snage i spojiti ih u zajedničkoj borbi za hrvatsku državnu samostalnost (Žižić, 2019, 85).

\subsection{Demokršćanska orijentacija}

Postojanje različitih i suprotstavljenih struja unutar vodstva HDZ-a postalo je vidljivo nakon državnoga osamostaljenja i uspješne obrane Hrvatske. Frakcijski sukobi unutar vodstva HDZ-a postali su toliko izraženi da od početka 1993. gotovo da nije bilo sjednice Predsjedništva HDZ-a na kojoj se Tuđman nije kritički osvrnuo na postojeće podjele unutar stranke (Miškulin, 2017, 380). Tuđman je te podjele tumačio u prvom redu posljedicama osobnih animoziteta, ali je bila sve očitija tendencija da ih objašnjava ideološkim razlozima koristeći se pritom izrazima "desno" i "lijevo" krilo stranke (Miškulin, 2017, 380). Svoje stajalište o podjelama u stranci i željenom političkom identitetu HDZ-a Tuđman je iznio na sjednici Vijeća obrane i nacionalne sigurnosti (VONS) održanoj 5. srpnja 1993.:

»Još je ostalo, znači, pitanje frakcija u HDZ-u. Da ima svaka stranka svoje središte, svoju ljevicu i svoju desnicu, to je neizbježivo u svim strankama u svijetu. Ali u svim strankama političkog svijeta ima ipak nešto što se zove provedba strategije jedne stranke, i tu ne može biti, ne mogu se zastupati različite politike, osobito kad je riječ o državnoj politici. [...]

Mislim da će HDZ ostati, jer na kraju ostvarit ćemo rezultate, ostat će narodna stranka. Mi ne trebamo, nećemo, ja neću dopustiti, barem dok sam ja živ, nikakve klerikalizacije, nego HDZ mora ostati u biti ono s čime smo pobijedili. Znači, jedna općenarodna stranka. Ali, molim, u svojim osnovama za demokršćansko opredjeljenje. Zašto? Zato da bi nas te demokršćanske, konzervativne narodne 
stranke Europe i svijeta primile. Jer, na žalost je tako, da ni jedna liberalna, ni jedna socijalistička stranka nije za samostalnu Hrvatsku «(Šeks, 2017, 107-108). ${ }^{11}$

Prema Tuđmanovoj zamisli u HDZ-u je trebalo biti mjesta za sastavnice koje je on percipirao kao lijevu i desnu, ali uz uvjet da obje budu podređene "središnjoj politici”, koja je za Tuđmana podrazumijevala prihvaćanje njegova neospornoga autoriteta i svehrvatskoga programa stranke, koji je objedinjavao starčevićanstvo, radićevštinu i hrvatsku ljevicu. ${ }^{12}$ Kako bi ojačao svoj osobni autoritet i spriječio prevlast lijeve ili desne sastavnice stranke, Tuđman se je tijekom 1993. odlučio za učvršćivanje "središnje politike" u obliku svjetonazorskoga i kadrovskoga profiliranja HDZ-a u smjeru demokršćanstva (Žižić, 2019, 88). Demokršćanska orijentacija imala je i pragmatičnu svrhu ulaznice za međunarodno pozicioniranje stranke jer je HDZ trebala približiti ulasku u organizaciju sličnih stranaka na europskoj razini (Miškulin, 2017, 411).

Tuđmanovo profiliranje HDZ-a u smjeru demokršćanstva započelo je kadrovskim promjenama u vodstvu stranke. U travnju 1993. Središnji odbor HDZ-a na Tuđmanov je prijedlog za dopredsjednike stranke izabrao Franju Gregurića, ${ }^{13}$ Hrvoja Šarinića, ${ }^{14}$ Juru Radića ${ }^{15}$ i Nikicu Valentića, ${ }^{16}$ a Mate Granić17 kao predsjednik HDZ-a Grada Zagreba po položaju je postao dopredsjednik. ${ }^{18}$ Sljedeći Tuđmanov korak u profiliranju HDZ-a u smjeru demokršćanstva bilo je usvajanje novoga programa i statuta stranke. U proslovu prijedloga novoga programa stajalo je da je HDZ »općehrvatska i općenarodna stranka nastala u posljednjem desetljeću 20. stoljeća kao najizvorniji izraz stoljetne težnje hrvatskog naroda za ostvarenje svoje slobode i samostalnosti« (HDZ, 1993, 14). Proslov novoga programa odredio je kako idejne osnove HDZ-a i dalje ostaju »hrvatska državotvorna misao Ante Starčevića, politički oslonac na pučke slojeve sela i grada po nauku braće Radića te politička odlučnost, socijalna pravda i antifašizam hrvatske ljevice« (HDZ, 1993, 14). U osnovnim načelima programa po prvi put je istaknuto demokršćansko opredjeljenje HDZ-a, koji je definiran kao »narodna stranka koja okuplja široke slojeve hrvatskog naroda i drugih građana Hrvatske, gradeći svoj program na demokršćanskim načelima«

11 Tekst koji se u ovom radu prenosi iz knjige Vladimira Šeksa (2017) nisu memoarski zapisi, nego dijelovi transkripata sjednica najviših državnih (VONS) i stranačkih tijela (Opći sabor, Predsjedništvo HDZ-a).

12 Tuđmanova podjela na lijevu i desnu sastavnicu HDZ-a nije bila uvjetovana različitim unutarstranačkim pogledima na socioekonomska i ideološko-kulturna pitanja, nego pripadnošću stranačkih prvaka i aktivista suprotstavljenim političkim tradicijama — tradiciji NOB-a (ljevica) i tradiciji NDH (desnica).

13 Franjo Gregurić (1939.), predsjednik hrvatske Vlade od 1991. do 1992. godine.

14 Hrvoje Šarinić (1935.-2017.), predsjednik hrvatske Vlade od 1992. do 1993. godine.

15 Jure Radić (1953.-2016.), potpredsjednik hrvatske Vlade od 1994. do 2000. godine.

16 Nikica Valentić (1950.), predsjednik hrvatske Vlade od 1993. do 1995. godine.

17 Mate Granić (1947.), hrvatski ministar vanjskih poslova od 1993. do 2000. godine.

18 Privatni arhiv Vladimir Šeks. 18/1 JG. Zapisnik sa sjednice Glavnog odbora Hrvatske demokratske zajednice, održane u Zagrebu, dana 12. travnja 1993. godine na Zagrebačkom velesajmu u dvorani Globus. 
(HDZ, 1993, 15). Kao cilj stranke navedeno je »demokratsko povezivanje svih ljudi koji su spremni u javnom i političkom djelovanju primjenjivati temeljne i općeljudske vrednote kršćanske civilizacije i morala, radi ostvarivanja novog duhovnog i materijalnog preporoda Hrvatske (HDZ, 1993, 15). Elementi demokršćanske ideologije istaknuti su određenjem kako HDZ za polazište ima »čovjeka kao osobu i sve vrednote koje su temelj općih demokratskih načela suvremena svijeta, a posebno kršćanskog poimanja života koje se sažimlju $\mathrm{u}$ nepovredivosti osobne časti, dostojanstva i slobode, u iskrenu ljubav prema bližnjem i poimanju obitelji kao nedodirljive osnovne ljudske zajednice na kojoj počivaju i iz koje proizlaze temeljne ljudske vrednote« (HDZ, 1993, 15). Demokršćansko programsko usmjerenje iskazano je i zauzimanjem za sustav socijalno-tržišnoga gospodarstva, uzajamnost, solidarnost i supsidijarnost. Demokršćanska orijentacija bila je istaknuta i u temeljnim načelima prijedloga novoga statuta HDZ-a.

Na sjednici Središnjega odbora HDZ-a 12. listopada 1993., na kojoj se je raspravljalo o prijedlozima novoga stranačkoga programa i statuta, tadašnji HDZov saborski zastupnik fra Tomislav Duka usprotivio se je ugradnji kršćanskih načela i demokršćanskoga usmjerenja u program HDZ-a. Duka je istaknuo kako »to znači da mi sužavamo djelotvorni prostor Hrvatske demokratske zajednice i da nekako marginaliziramo one ljude koji možda nisu previše usmjereni prema kršćanskim načelima, ali su i te kakovi veliki humanisti i ljubitelji Hrvatske «. ${ }^{19}$ Upozorio je i na nespojivost prihvaćanja kršćanskih načela i primjene brojnih zakona iz komunističkoga razdoblja, pri čemu je kao primjer naveo tadašnji hrvatski zakon o pobačaju. ${ }^{20} \mathrm{U}$ svojem odgovoru na Dukine primjedbe Tuđman je istaknuo kako HDZ »mora svoje ciljeve i svu svoju djelatnost temeljiti na dosadašnjim iskustvima i na programskim osnovama na kojima je ostvario sve stečevine, učvršćujući svoj program i svoju djelatnost načelima kršćanske civilizacije zapadnog svijeta kojemu hrvatski narod oduvijek pripada «. ${ }^{21} \mathrm{U}$ pogledu naslanjanja stranke na načela kršćanske civilizacije Tuđman je dalje dodao:

»To je dovoljno neodređeno, ali i dovoljno određeno.

Dovoljno određeno zato da bi nas narodne stranke i stranke kršćansko-demokratske orijentacije prihvatile u svoj krug u koji želimo ići i dobiti njihovu potporu u međunarodnom području.

A načela kršćanske civilizacije gospodo obuhvaćaju sve, ako hoćete i iz kršćanske civilizacije i socijaldemokracija je proizašla, i socijalističke teorije su proizašle iz kršćanske civilizacije. [...]

19 Privatni arhiv Vladimir Šeks. 5/1 HLJ. Zapisnik sa sjednice Središnjeg odbora Hrvatske demokratske zajednice održane 12. listopada 1993. godine.

20 Privatni arhiv Vladimir Šeks. 5/1-5/2 HLJ. Zapisnik sa sjednice Središnjeg odbora Hrvatske demokratske zajednice održane 12. listopada 1993. godine.

21 Privatni arhiv Vladimir Šeks. 6/2 HLJ. Zapisnik sa sjednice Središnjeg odbora Hrvatske demokratske zajednice održane 12. listopada 1993. godine. 
Mi isto tako ne želimo - i o tome smo raspravili — biti nikakva, najmanje klerikalna stranka $\ll^{22}$

\subsection{Svehrvatska stranka na načelima kršćanske civilizacije}

Najavljujući Drugi opći sabor HDZ-a, koji je bio zakazan za 15. i 16. listopada 1993., Tuđman je istaknuo da će u vrhu stranke doći »do takvih promjena koje će dati jasnu naznaku u kom smislu HDZ želi ići svojim središnjem putem«, dodajući kako »u tom smislu ne može biti kolebanja da HDZ želi biti općehrvatska i općenarodna stranka na načelima kršćanske demokracije « (Peakić-Mikuljan, 1993, 7). Na Drugom općem saboru Tuđman je predložio nove kandidate za vodstvo stranke, među kojima nije bilo istaknutih predstavnika lijeve i desne struje HDZ-a poput Josipa Manolića i Vladimira Šeksa. Tuđmanovi kandidati bili su Mate Granić, Nikica Valentić, Franjo Gregurić, Gojko Šušak i Marijan Šunjić za podpredsjednike te Jure Radić za glavnoga tajnika stranke. Njihove je kandidature Tuđman obrazložio ističući da je riječ o ljudima »koji su, znači, za središnju politiku, koji su tog opredjeljenja HDZ-a, na kontinuitetu, ali i na načelima kršćanske civilizacije « (Šeks, 2017, 212). Glasovanje izaslanika na stranačkom saboru potvrdilo je spomenute Tuđmanove kandidate za najuže stranačko vodstvo. Stranački sabor usvojio je i novi stranački program, u kojem je istaknuto demokršćansko opredjeljenje HDZ-a. U novi program HDZ-a bile su ugrađene temeljne odrednice katoličkoga socijalnoga nauka i demokršćanske ideologije - dostojanstvo osobe, odnosno apsolutna vrijednost čovjeka, solidarnost, supsidijarnost, sudioništvo i zajedničko dobro (Petrač, 1994, 115). U osvrtu na Drugi opći sabor Tuđman je naglasio spominjanje načela kršćanske demokracije u proslovu novoga programa, pritom ističući kako »HDZ ne postaje demokršćanska stranka, nego je općenarodna i općehrvatska stranka « (Mijatović, 1999, 176).

Nakon Drugoga općega sabora produbio se je sukob unutar vodstva HDZ-a oko hrvatske politike prema vojnomu sukobu Hrvata i Bošnjaka u Bosni i Hercegovini (BiH). Frakcija stranke koja je percipirana kao lijeva stranačka struja izražavala je nezadovoljstvo Tuđmanovom i hrvatskom podrškom Hrvatskoj Republici Herceg-Bosni (HR HB) u BiH te općenito političkom orijentacijom stranke. Na sjednici Predsjedništva HDZ-a sredinom siječnja 1994. glavni predstavnik lijeve struje Josip Manolić iznio je mišljenje kako je demokršćansko profiliranje HDZ-a »bila kardinalna greška, strateška greška u kreiranju stranke, politike u toj stranki« (Šeks, 2017, 371). U pogledu transformacije HDZ-a u demokršćansku stranku Manolić je ustvrdio:

»Da smo izvršili analizu što imamo od demokršćana u Hrvatskoj, da imamo tri stranke, da sve tri nisu dobile niti ulaz u Sabor, vjerojatno bismo trezvenije prišli tome problemu. Jasno da je onima koji su zastupali demokršćanstvo i prijelaz stranke u demokršćane, da su morali onda izmisliti da treba otpiliti te suhe

22 Privatni arhiv Vladimir Šeks. 6/3 HLJ. Zapisnik sa sjednice Središnjeg odbora Hrvatske demokratske zajednice održane 12. listopada 1993. godine. 
grane, kako su ih nazvali, u licu Manolića, Degoricije, ${ }^{23}$ Gažija ${ }^{24}$ i ne znam koga su sve nabrojali. Mislim da je to uneslo u pravom momentu jedno neraspoloženje osobno kod mene, a drugo, izazvalo je nedoumicu kod širokog kruga stranačkih ljudi koji su stvarali ovu HDZ stranku ili pokret. [...]

Mene neki dan na radiju pitaju, vi ste rekli da nećete biti demokršćanin. Dok postoji ovaj program na kojem smo gradili HDZ, tako dugo ja ne mogu postati demokršćanin. Ili ću biti demokršćanin ili ću biti HDZ-ovac« (Šeks, 2017, 371).

U svojem istupu na spomenutoj sjednici Tuđman je branio transformaciju HDZ-a iz pokreta u stranku te marginalizaciju lijeve i desne sastavnice stranke. U odnosu na profiliranje HDZ-a u smjeru demokršćanstva, Tuđman je istaknuo:

»Ali ja sam na saboru [HDZ-a] lijepo rekao, ne želim nikakvu usku demokršćansku stranku. Rekao sam da HDZ mora ostati u osnovi ono kako je nastalo, znači općehrvatska i općenarodna stranka koja će svoj program temeljiti — doslovce sam rekao i mislim da ste to valjda u programu i kasnije vidjeli — temeljiti na načelima kršćanske civilizacije. [...]

I još nešto, bio sam za to da se metne to na načelima kršćanske civilizacije $i$ da se povezujemo sa kršćansko-demokratskim, narodnim, među inim i zato što je većina hrvatskog naroda ipak, i u anketama ćete vidjeti, i u cjelini smo ipak mi pobijedili osloncem na Crkvu i te i takve društvene slojeve kakvi oni jesu, sada su dvije trećine hrvatskog naroda vezane uz Crkvu, uz religiju, itd. Prema tome, orijentacija je naša bila ispravna i s time smo pobijedili« (Šeks, 2017, 382-383).

Tuđmanov sukob s frakcijom HDZ-a oko Manolića i Stjepana Mesića oko politike prema ratu u $\mathrm{BiH}$ i političke orijentacije stranke rezultirao je uklanjanjem Manolića sa stranačkih dužnosti i odcjepljenjem spomenute frakcije, koja je pod vodstvom Manolića i Mesića osnovala novu stranku, Hrvatske nezavisne demokrate (HND). Nova stranka je nastojala pridobiti dovoljan broj parlamentarnih zastupnika HDZ-a da se promijeni odnos snaga u Saboru i prisili Tuđmana kao predsjednika države na neku vrstu kohabitacije s novom parlamentarnom većinom. Premda su Manolić i Mesić kao visoki dužnosnici HDZ-a i predsjednici parlamentarnih domova uživali veliki autoritet i utjecaj među HDZ-ovim zastupnicima, HDZ-ov je zastupnički klub ostao lojalan Tuđmanu i naposljetku je smijenio Manolića i Mesića s čelnih položaja u Saboru. Uslijed sukoba s odmetnutom frakcijom stranke Tuđman je početkom travnja 1994. prisustvovao sjednici Kluba zastupnika HDZ-a. U obraćanju HDZ-ovim zastupnicima Tuđman je istaknuo da se je na Drugom općem saboru izjasnio protiv pretvaranja HDZ-a u »nekakvu usko demokršćansku stranku « zauzimajući se da HDZ ostane »općehrvatska, općenarodna stranka, koja svoj program zasniva na načelima kršćanske civilizacije« (Tuđman, 1995, 364).

I u kasnijim programskim govorima Tuđman je HDZ primarno određivao kao svehrvatsku stranku čiji je program utemeljen na načelima kršćanske civilizacije. U uvodnom govoru na 2. sjednici Glavnoga odbora HDZ-a 7. prosinca

23 Slavko Degoricija, tadašnji saborski zastupnik HDZ-a.

24 Ivica Gaži, tadašnji saborski zastupnik HDZ-a. 
1996. Tuđman se je založio za očuvanje i jačanje jedinstva HDZ-a »kao središnje općenarodne državotvorne i demokratske stranke, koja svoj program i djelatnost zasniva na načelima kršćanske civilizacije « (Tuđman, 1996). U uvodnom izlaganju na 4. Općem saboru HDZ-a 21. veljače 1998. Tuđman je istaknuo da HDZ treba djelovati »kao dosljedna općenarodna stranka svih društvenih stališa, svih društvenih slojeva « (Tuđman, 1998, 63). Na sjednici Glavnoga odbora HDZa 26. lipnja 1999. Tuđman je istaknuo kako »HDZ od svojeg programa pa sve do sada provodi politiku na načelima i iskustvu kršćanske civilizacije, jer su se oni pokazali najvjerodostojnijim i najmoralnijim temeljem cjelokupne politike« (Tuđman, 1999, 19).

\section{Zaključak}

U skladu s Tuđmanovim naumom HDZ se je na stranačkom saboru 1993. programski odredio kao stranka demokršćanske ideološke orijentacije. Tuđmanovo profiliranje HDZ-a u stranku demokršćanske orijentacije bilo je motivirano dvama pragmatičnim razlozima: prvo, trebalo je učvrstiti srednju liniju HDZ-a, što je podrazumijevalo jačanje Tuđmanova autoriteta i slabljenje utjecaja ljevice i desnice u stranci, i drugo, trebalo je HDZ približiti europskim demokršćanskim i konzervativnim strankama te poboljšati međunarodni ugled stranke. No isticanje demokršćanskih elemenata u programu HDZ-a nije za Tuđmana značilo da ta stranka napušta svoj nadideološki i svehrvatski politički identitet i postaje izričito demokršćanska stranka. Kako pokazuju njegovi kasniji programski govori na najvišim stranačkim tijelima, Tuđman je HDZ primarno vidio kao svehrvatsku stranku čiji je program zasnovan na načelima kršćanske civilizacije, a ne kao stranku demokršćanske ideološke orijentacije. Tuđmanova zamisao da HDZ politički artikulira interese cijeloga hrvatskoga naroda bila je i u neskladu s praksom suvremenih demokršćanskih stranaka koje nemaju pretenziju obuhvatiti sav narod (Burić, 2002, 164).

Tuđmanovo naglašavanje kako demokršćanski opredijeljeni HDZ ne želi »biti nikakva, najmanje klerikalna stranka« niti se želi pretvoriti u »nekakvu usko demokršćansku stranku « pokazuju da je njegovo razumijevanje demokršćanstva bilo prilično rudimentarno i puno bliže konfesionalnoj nego suvremenoj fazi demokršćanstva. Takvo razumijevanje bilo je svojstveno postkomunističkim državama Europe, u kojima su demokršćanske stranke bile poistovjećene s klerikalizmom i stajalištima Crkve u pogledu javnih politika, a ne sa širokim kršćanskim učenjem, konzervativnim socijalnim tržištem i eksplicitno neklerikalnim i nenacionalističkim zahtjevima za opće vrijednosti. U tim je zemljama demokršćanska orijentacija podrazumijevala specifično i usko biračko tijelo, povezivala stranku s Crkvom i implicirala proklerikalnu doktrinu (Gryzmala-Busse, 2011, 325-326).

No Tuđmanov odnos prema demokršćanskom opredjeljenju HDZ-a pokazuje i neka obilježja suvremenoga demokršćanstva. Tuđman je ustrajavao da se HDZ programski zasniva na »načelima kršćanske civilizacije «, što je prilično neodređen pojam koji je inkluzivan i prema pripadnicima drugih religija, pa čak 
i ateistima i agnosticima. Takvo shvaćanje demokršćanske orijentacije HDZ-a blisko je suvremenomu i sekulariziranomu obliku demokršćanstva u kojem se religijska pripadnost pokazuje isključivo neodređenim pojmovima kao što su »religijska inspiracija « $\mathrm{i}$ »vrijednosti kršćanske civilizacije « (Kalyvas i Kersbergen, 2010, 188).

\section{Literatura}

Anon. (2016). Mesić: Tuđman nije želio demokršćanstvo u HDZ-u. U: Index, 22. lipnja. URL: https://www.index.hr/vijesti/clanak/mesic-tudjman-nije-zelio-demokrscanstvo-u-hdzu/901513.aspx (10.01.2020.)

Anon. (2020). Mesić za N1 o Franji Tuđmanu, Muhamedu Zuliću i demokršćanskom HDZ-u Hrvatske. U: N1 BiH. URL: http://ba.n1info.com/Vijesti/a402560/Mesic-zaN1-o-Franji-Tudjmanu-Muhamedu-Zulicu-i-demokrscanskom-HDZ-u-Hrvatske.html (10.01.2020.)

Baloban, Stjepan (1995). Pitanje demokracije u socijalnim dokumentima Crkve. Politička misao, 32(1), 31-38.

Boban, Ljubo (1995). Kršćanska demokracija u hrvatskoj stranačko-političkoj tradiciji. Politička misao, 32(2), 199-206.

Brozović, Dalibor (ur.) (2000). Hrvatska enciklopedija: 2: Be-Da. Zagreb: Leksikografski zavod Miroslav Krleža.

Burić, Christian (2002). O mogućnostima reformiranja HDZ-a: Aspekti puta u kršćanskodemokratsku stranku. Politička misao, 39(1), 159-165.

Caramani, Daniele (2013). Stranački sustavi. U: Daniele Caramani (ur.), Komparativna politika (str. 235-257). Zagreb: Fakultet političkih znanosti.

Cipek, Tihomir (2004). Christliche Demokratie in Kroatien. U: Günter Buchstab i Rudolf Uertz (ur.), Christliche Demokratie im zusammenwachsenden Europa: Entwicklungen, Programmatik, Perspektiven (str. 336-355). Freiburg im Breisgau: Herder.

Cipek, Tihomir (2006). Ideologija i nacije - političke stranke u Austro-Ugarskoj Monarhiji. U: Tihomir Cipek i Stjepan Matković (ur.), Programatski dokumenti hrvatskih političkih stranaka i skupina 1842.-1914. (str. 15-48). Zagreb: Disput.

Cipek, Tihomir (2016). Neposredna demokracija u ideologiji HSS-a. U: Zorislav Lukić i Hrvoje Petrić (ur.), 110 godina Hrvatske seljačke stranke: Zbornik radova (str. 13-24). Zagreb: Matica hrvatska.

Cvrlje, Vjekoslav (1994). Vatikan i kršćanska demokracija u Italiji. Politička misao, 31(4), 57-69.

Đurić, Dragan; Munjin, Bojan; Španović, Srđan (1990). Stranke u Hrvatskoj. Zagreb: NIRO Radničke novine.

Grbac, Josip (2007). Političke stranke s kršćanskim predznakom u Hrvatskoj: mogućnosti i potrebe? Bogoslovska smotra, 77(2), 453-468.

Gryzmala-Busse, Ann (2011). Why there is (almost) no Christian Democracy in postcommunist Europe. Party Politics, 19(2), 319-342.

Hanley, David (1994). Christian Democracy as a Political Phenomenon. U: David Hanley (ur.), Christian Democracy in Europe: A Comparative Perspective (str. 1-11). London: Pinter.

HDZ (1989). Prednacrt programske osnove Hrvatske demokratske zajednice. Bilten za članstvo, 1(1), 4-7.

HDZ (1993). Prijedlog programa Hrvatske demokratske zajednice (1993). Glasnik Hrvatske demokratske zajednice, 5 (8. listopada), 14-23. 
HDZ (2018). Statut Hrvatske demokratske zajednice. 26. svibnja. URL: https://hdz.hr/userfiles/pdf/hdz_statut_2018.pdf (22.06.2020.)

Hina (2017). Plenković položio vijenac i zapalio svijeću kod rodne kuće prvog predsjednika. U: Jutarnji list, 12. svibnja. URL: https://www.jutarnji.hr/vijesti/hrvatska/plenkovic-polozio-vijenac-i-zapalio-svijecu-kod-rodne-kuce-prvog-predsjednika-hdzove-godine-zelim-pozicionirati-gdje-bi-to-tudman-zelio/6053909/ (10.01.2020.)

Hina (2018). Plenković: Bez braniteljske potpore ne bi bilo ni hrvatske slobode. U: Tportal, 29. rujna. URL: https://www.tportal.hr/vijesti/clanak/plenkovic-bez-braniteljskepotpore-ne-bi-bilo-ni-hrvatske-slobode-foto-20180929 (10.01.2020.)

Hornig, Eike-Christian (2013). The Genetic Origin of the CDU and its Developmental Path to a Catch-All Party. German Politics, 22(1-2), 82-96.

Jukić, Jakov (2001). Idejna i kulturološka strujanja u javnom životu hrvatskog naroda u razdoblju od 1918. do 1941. Društvena istraživanja, 10(1-2), 3-18.

Kalyvas, Stathis N.; Kersbergen, Kees van (2010). Christian Democracy. Annual Review of Political Science, 13, 183-209.

Karlović-Sabolić, Marina (2018). Je li Plenković briselski ćato ili vođa za moderno doba? U: Slobodna Dalmacija, 15. travnja. URL: https://slobodnadalmacija.hr/vijesti/hrvatska/je-li-plenkovic-briselski-cato-ili-voda-za-moderno-doba-hdz-nije-demokrscanska-stranka-niti-ga-je-tudman-ikad-tako-zamislio-541556 (10.01.2020.)

Krnetić, Snježana (2019). »Kritiziraju nas oni koji bi bez HDZ-a bili nitko i ništa«. U: Express. URL: https://express.24sata.hr/top-news/kritiziraju-nas-oni-koji-bi-bezhdz-a-bili-nitko-i-nista-21402 (10. 01. 2020.)

Markešić, Ivan (2007). Političke stranke i religija — hrvatski slučaj. U: Anđelko Milardović, Dražen Lalić i Zoran Malenica (ur.), Kriza i transformacija političkih stranaka (str. 39-61). Zagreb: Centar za politološka istraživanja.

Mašić, Barbara (2010). Stranačka struktura Hrvatskog sabora 1990.-2010. Pravnik, 44(89), 67-82.

Matijević, Zlatko (1997). Katolici i politika: Spor između stranačkog Hrvatskog katoličkog pokreta i izvanstranačke Katoličke akcije (1912.-1929. godine). Časopis za suvremenu povijest, 29(3), 437-456.

Matković, Stjepan (2006). Obilježja političko-stranačkih kretanja u banskoj Hrvatskoj, Dalmaciji, Istri i Bosni i Hercegovini 1842.-1914. U: Tihomir Cipek i Stjepan Matković (ur.), Programatski dokumenti hrvatskih političkih stranaka $i$ skupina 1842.-1914. (str. 49-97). Zagreb: Disput.

Mijatović, Anđelko (1999). Deset godina Hrvatske demokratske zajednice (kronologija). U: Anđelko Mijatović (ur.), Deset godina Hrvatske demokratske zajednice (str. 95-219). Zagreb: Hrvatska demokratska zajednica.

Milardović, Anđelko (1994). Kršćanska demokracija u Europi. Osijek: Panliber.

Miškulin, Ivica (2017). Šeks: Politička biografija. Zagreb: Alfa.

Nikić Čakar, Dario (2013). Prezidencijalizacija političkih stranaka: komparativna analiza britanske Laburističke stranke, Španjolske socijalističke radničke stranke i Hrvatske demokratske zajednice. Zagreb: Fakultet političkih znanosti.

Peakić-Mikuljan, Marija (1993). Kao da su prošla tri desetljeća. Glasnik Hrvatske demokratske zajednice, 5 (8. listopada), 4-9.

Pelinka, Anton (2004). European Christian Democracy in Comparasion. U: Michael Gehler i Wolfram Kaiser (ur.), Christian Democracy in Europe since 1945 (str. 169-180). London: Routledge.

Petrač, Božidar (1994). Hrvatska demokratska zajednica i kršćanska demokracija. Politička misao, 31(4), 111-116. 
Pombeni, Paolo (2006). Ideologija kršćanske demokracije. U: Michael Freeden (ur.), Političke ideologije: novi prikaz (str. 119-133). Zagreb: Algoritam.

Radja, Tihomil (1998). Katolicizam i liberalizam u politici Stjepana Radića. U: Hans-Georg Fleck (ur.), Liberalizam i katolicizam u Hrvatskoj (str. 99-105). Zagreb: Zaklada Friedrich Naumann.

Raos, Višeslav (2014). Demokršćanstvo danas. Vijenac, 22(522). URL: http://www.matica. $\mathrm{hr} / \mathrm{vijenac} / 522 /$ demokrscanstvo-danas-22954/ (12.01.2020.)

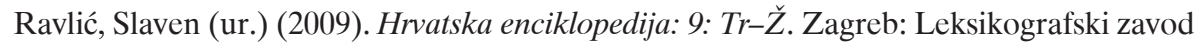
Miroslav Krleža.

Strecha, Mario (2004). Od katoličkog hrvatstva do katoličkog pravaštva. Radovi Zavoda za hrvatsku povijest Filozofskoga fakulteta Sveučilišta u Zagrebu, 34-35-36, 101-133.

Šeks, Vladimir (2017). Državni udar: Kako su Manolić i Mesić rušili Tuđmana i hrvatska politika prema BiH: 1. dio. Zagreb: Večernji list.

Tuđman, Franjo (1995). S vjerom u samostalnu Hrvatsku. Zagreb: Narodne novine.

Tuđman, Franjo (1996). Uvodni govor Predsjednika dr Franje Tuđmana na 2. sjednici Glavnog odbora HDZ-a 7. prosinca 1996. URL: https://hr.wikisource.org/wiki/ Uvodni_govor_Franje_Tu\%C4\%91mana_na_2._sjednici_Glavnog_odbora_HDZ-a (15.01.2020.)

Tuđman, Franjo (1998). HDZ - stožerna stranka demokratske Hrvatske. Zagreb: Hrvatska demokratska zajednica.

Tuđman, Franjo (1999). Povijesna ostvarenja i daljnja uloga HDZ-a. U: Vlatko Previšić i Tomislav Salopek (ur.), Sjednica Glavnog odbora i svih tijela HDZ-a: Zbornik (str. 12-23). Zagreb: Hrvatska demokratska zajednica.

Žižić, Jakov (2019). Analiza izvora moći političkoga vodstva Franje Tuđmana (Doktorski rad). Fakultet političkih znanosti, Sveučilište u Zagrebu.

Arhivsko gradivo

Privatni arhiv Vladimir Šeks.

Franjo Tudman, Democratic Christianity and the Croatian Democratic Union Jakov Žižić*

\section{Summary}

In Croatian public discourse, there exist different interpretations of Franjo Tudman's position on Christian democracy and his vision of the Croatian Democratic Union (HDZ ) as a Christian democratic party. Some of the former officials of HDZ deny that Tudman was a Christian democrat and that HDZ was a Christian democratic party during the 1990's. On the other hand, today's party leadership points out that Tudman established HDZ on the principles of Christian democracy. By using primary and secondary sources and existing literature, this article examines Franjo Tudman's position in regard to the Christian democratic orientation of HDZ and his

* Jakov Žižić, Ph.D., Teaching Assistant, Catholic University of Croatia. Address: Ilica 242, 10000 Zagreb, Croatia. E-mail: jakovzizic@unicath.hr 
understanding of Christian democracy. We present Tudman's views on the political identity of HDZ and explain the transformation of HDZ into a party with a Christian democratic orientation at the 1993 party congress. An empirical analysis showed that Tudman did not want HDZ to abandon its trans-ideological and all-Croatian political identity and become an explicitly Christian democratic party, despite the party's programmatic transition to Christian democratic principles. The analysis also revealed that Tudman's understanding of Christian democracy was much closer to the confessional than to the contemporary phase of Christian democracy, although some features indicate that Tudman endorsed the contemporary form of the Christian democratic ideology.

Keywords: Franjo Tudman; Croatian Democratic Union; Christian democracy; Christian democratic parties; Croatian parties 